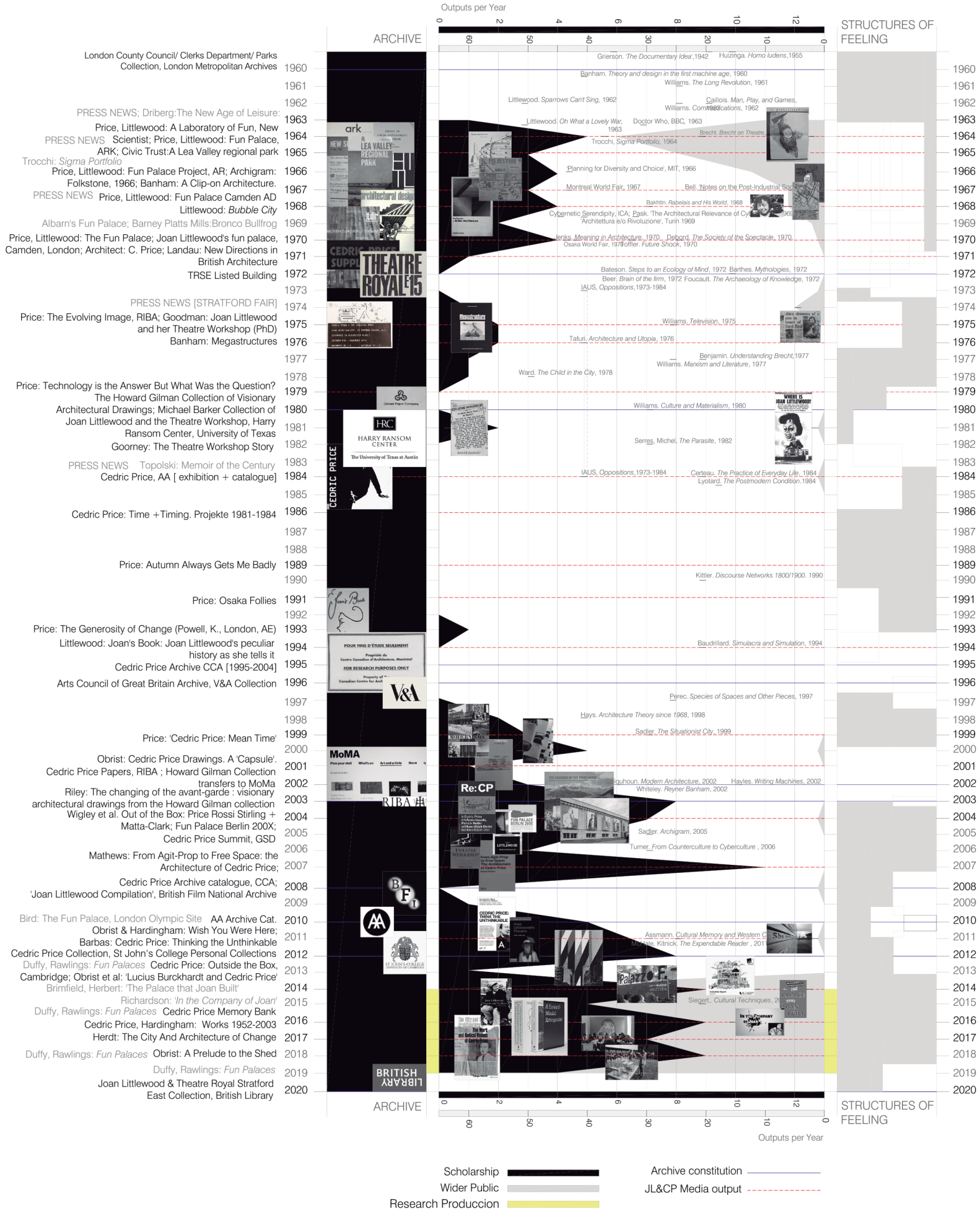




\section{Authorship and the Archive: The Reception of the Fun Palace Project Ana Bonet Miró}

The Fun Palace, a landmark cultural complex that was initiated in London in 1961 by Joan Littlewood and Cedric Price and followed an increasingly mobile agenda until 1975, circulates relentlessly in architectural scholarship today. Yet the cultural agenda of the project that emanates from the archive and Littlewood's role in it seems to have been neutralized. This article reconstructs the almost sixtyyear history of the reception of the Fun Palace so as to critically investigate the conditions that informed the distinctive afterimages of the project. The complex topology of the Fun Palace archive is regarded as a main agency that is constitutive of the project's modes of reception today: scholarship and activism.

\section{KEYWORDS}

Joan Littlewood, Cedric Price, Fun Palace, Non-architecture, Authorship, Complex Archive, Critical Reception

\section{PALABRAS CLAVE}

Joan Littlewood, Cedric Price, Fun Palace, no-arquitectura, autoría, archivo complejo, recepción crítica

More often than one might anticipate, images of the Fun Palace, a landmark cultural complex developed by Joan Littlewood and Cedric Price in London between 1961 and 1975, find their way into lectures, syllabi, exhibitions, and scholarly publications connected with architectural discourse. In 2019 for instance -before the pandemic Covid-19 impacted cultural activity worldwide- eight Fun Palace drawings were included in the exhibition Impossible Architectures at the Museum of Modern Art in Saitama, an investigation of visionary architectures of the twentieth century that operated at the frontiers of the social experience of their time. ${ }^{1}$ The project was also cited in the

\section{Ana Bonet Miró}

is lecturer in Architectural Design at the University of Edinburgh since 2015, and a chartered architect in the United Kingdom and Spain. She studied and has lectured and practiced architecture in Spain. She is a co-founder, along with Luca Brunelli, of bblab in 2000, an architecture laboratory that has developed designs that have been awarded prizes internationally and been published in Elemental: Incremental Housing and Participatory Design Manual (Hatje Cantz, 2012, 2016), Häuser Award (Callwey Verlag, 2012), Madrid 100\% II (COAM, 2011); Informes de la Construcción (CSIC, 2007), and Arquitectos (CSCAE, 2007). Her doctoral research on Joan Littlewood and Cedric Price's Fun Palace (1961-75), developed at the University of Edinburgh under the supervision of Prof. Mark Dorrian, has been published in Architecture and Culture, ARQ: Architectural Research Quarterly, and at drawingmatter.org. More broadly, her research focuses on the cultural dimension of architectural artifacts and discourses.

E-Mail: Ana.Bonet@ed.ac.uk ORCID iD: 0000-0003-1286-7659

Fig. 01

Fun Palace Reception Chart. Produced by the author. 
Fig. $\mathrm{O} 2$

Reyner Banham, “Clip-On Architecture," Design Quarterly, June 1965, pp. 14-15. broadly framed visual collection 'An Atlas of Architectural Theory' at the Círculo de Bellas Artes, Madrid, and in the Price-centered exhibition Cedric Price: Room for Learning at the Woodbury University Hollywood Gallery, Los Angeles. ${ }^{2}$ Meanwhile, the Fun Palace-inspired cultural center The Shed, designed by Diller\& Scofidio + Renfro and part of a high-end urban development in Hudson Yards, Manhattan, has opened its doors. ${ }^{3}$ And the international architectural competition "Macau [morphosis] Waterfront Fun Palace" was launched to envision alternative urban models to the city's current gambling culture. ${ }^{4}$ Moreover, the steady flow of architectural scholarship also keeps accumulating commentary on the project. $^{5}$

Why is the Fun Palace saturating architectural discourse more and more today? What kinds of image has the reception of the Fun Palace produced and reinforced in its almost sixty-year long history? Animated by specific disciplinary interests, Fun Palace afterimages appear to obscure, this article argues, the cultural complexity of the project -and the key role that Littlewood played in its development- in favor of what cultural critic Raymond Williams referred to as selective traditions. Rather than being definite objects, traditions are actively constituted by the reception of a work under the contingent system of values that is prevalent at that particular moment. The survival of a past life-claims Williams- "is governed, not by the period itself, but by new periods, which gradually compose a tradition. . . It is not an absolute body of work, but a continual selection and interpretation."
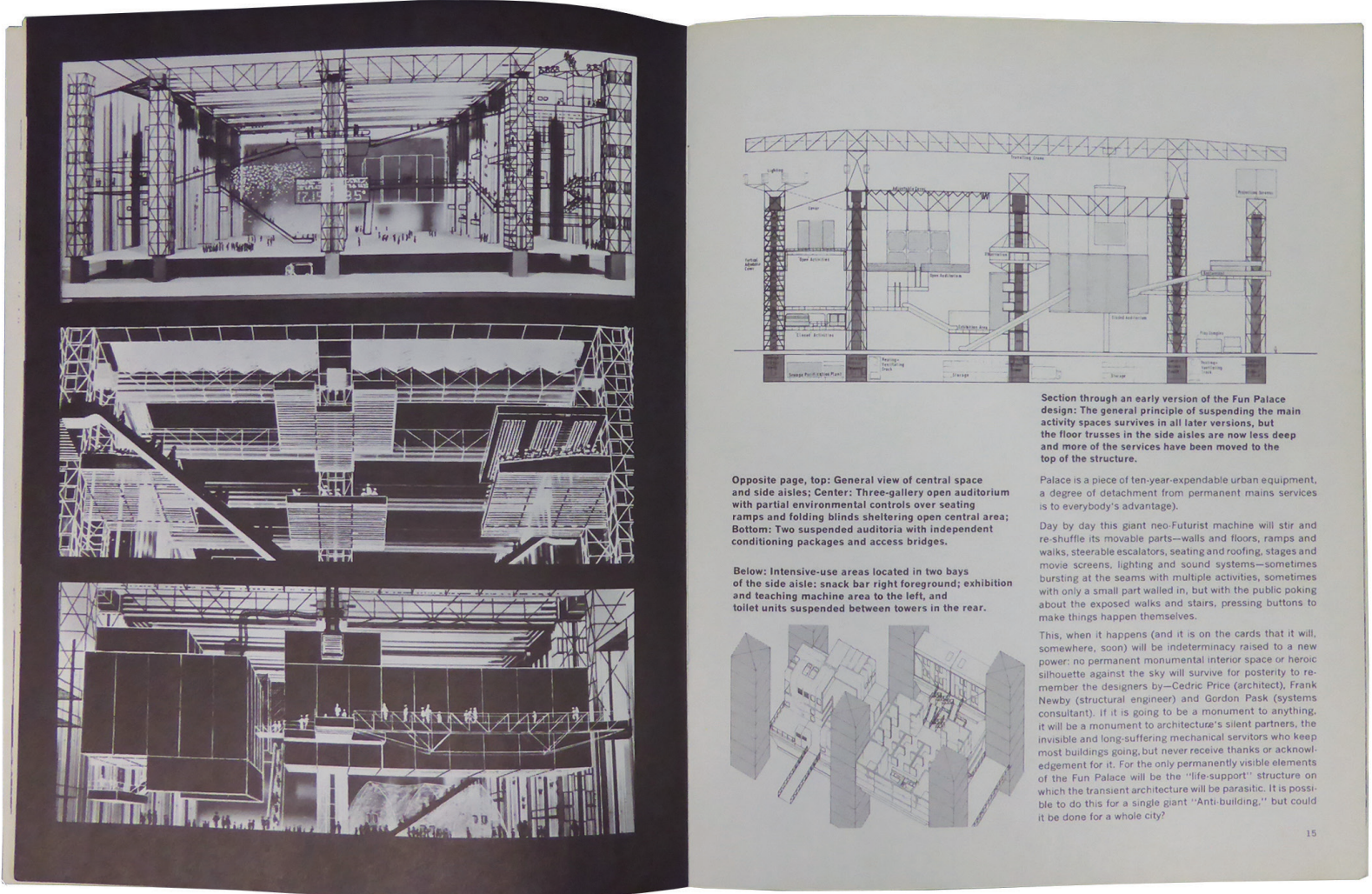
This article reconstructs the history of the reception of the Fun Palace in order to critically investigate the conditions and agencies involved in the construction of the project's distinctive traditions. As a preamble, the "Fun Palace Reception Chart" offers a visual organization of the complex afterlife of the Fun Palace until today. A black silhouette registers the appearance of the project in scholarly events such as those mentioned earlier in chronological order, and grounds it in available primary sources over time, including articles by Price and Littlewood and the step-by-step constitution of the archive on the project. Mirroring this, a light grey silhouette depicts the circulation of the project within broader public events. These are accompanied by a negative figure, that "other" life of the project, which is not included in the archive (fig. 01). The distinctive periodization that emerges from the chart determined the structure of this article. There was active scholarly interest in the Fun Palace through the 1960s and early 70s, which subsequently dipped before resurfacing at the turn of the twenty-first century. Animated by historical disciplinary interests, its pulse also appears to follow the tempo of the constitution of the different sections of the Fun Palace archive, as if these two conditions served to animate one other. The article thus concludes by reflecting on the agency of the archive in shaping the distinctive modes of how the project has been received until today.

THE ALTERITY OF INDETERMINACY IN THE 1960s AND EARLY 1970s
The concept of radical -or "anti"- architecture that characterizes the Fun Palace project today was first elaborated by the historian Reyner Banham. In his "Clip-On Architecture" (1965), the Fun Palace featured as a ready-to-be-built example of British "architecture of indetermi-

nate form," whose inchoate history his article investigated. ${ }^{7}$ Alongside the Fun Palace, Archigram's Plug-In City and the Entertainments Tower at the Montreal Expo of 1970 were also nascent, technologically infused components of urban systems proposed as alternatives to those consolidated by Stirling \& Gowan and the Smithsons. The neutral, anonymous, and repetitive aesthetics of the factory facades of the early 1950 s in the United States, and its corresponding developments in Britain, such as Sheffield's large-scale Park Hill public housing estate and the façade of Northwick Park Hospital, London, were their precedent. The generative schema of a cell with services was also implied in Smithson's House of the Future. Replete with images, Banham's article reproduces three promotional photomontages that Price had produced for Architectural Review, ${ }^{8}$ along with other key drawings of the major project and Camden Pilot schemes, so as to hail the key contribution of the project -along with that of Archigram- to a worldwide "architecture of indeterminacy" (fig. 02). ${ }^{9}$ The project joined an international range of speculations on the urban nurtured by the exhausted canon of modern architecture in the symposium "International Dialogue of Experimental Architecture," which was organized by Archigram in $1966 .^{10}$ Meanwhile, Price shared his agenda of responsive design - what he referred to as "calculated uncertainty"- more broadly with planners, social scientists, and philosophers in the conference "Planning for Diversity and Choice: Possible Futures and their Relations to the Man-Controlled Environment," which was held at the Massachusetts Institute of Technology the same year. "Calculated uncertainty is concerned" -Price claims: 
Fig. 03

Royston Landau, 1968, New Directions in British Architecture, pp. 74-75.
“... with an order that we establish for progress that doesn't have, and never wants, a particular goal in any physical terms. If, in fact, the generative force of architecture should be calculated change, then the question of planned obsolescence employed in the artifactual act is primarily what I am suggesting. Therefore, I am convinced that the valid social life of the activity that one is asked to shelter or encourage is the governing factor of whatever is produced; and that need not always be a building."

Price's principle of "calculated uncertainty" would find a most fervent instigator in the historian Royston Landau. By re-situating Banham's visual approach to indeterminate architecture as an approach rooted in a scientific basis, Landau's New Directions in British Architecture (1968) argued that information and communication technology would radically transform architecture into non-architecture, thus challenging the concurrent deterministic master planning of British "New Towns" since the Abercrombie era. The argument for an architecture autre was illustrated with a selection of Fun Palace images similar to those found in Banham's article of three years before. Landau, however, now added drawings from Price's Potteries Thinkbelt and Oxford Corner House, a range of new Archigram productions, and Banham's and Dallagret's Environment Bubble. These shared pages, et al., with non-deterministic plans such as the infrastructural grid for Colin Buchanan's Southampton-Portsmouth City

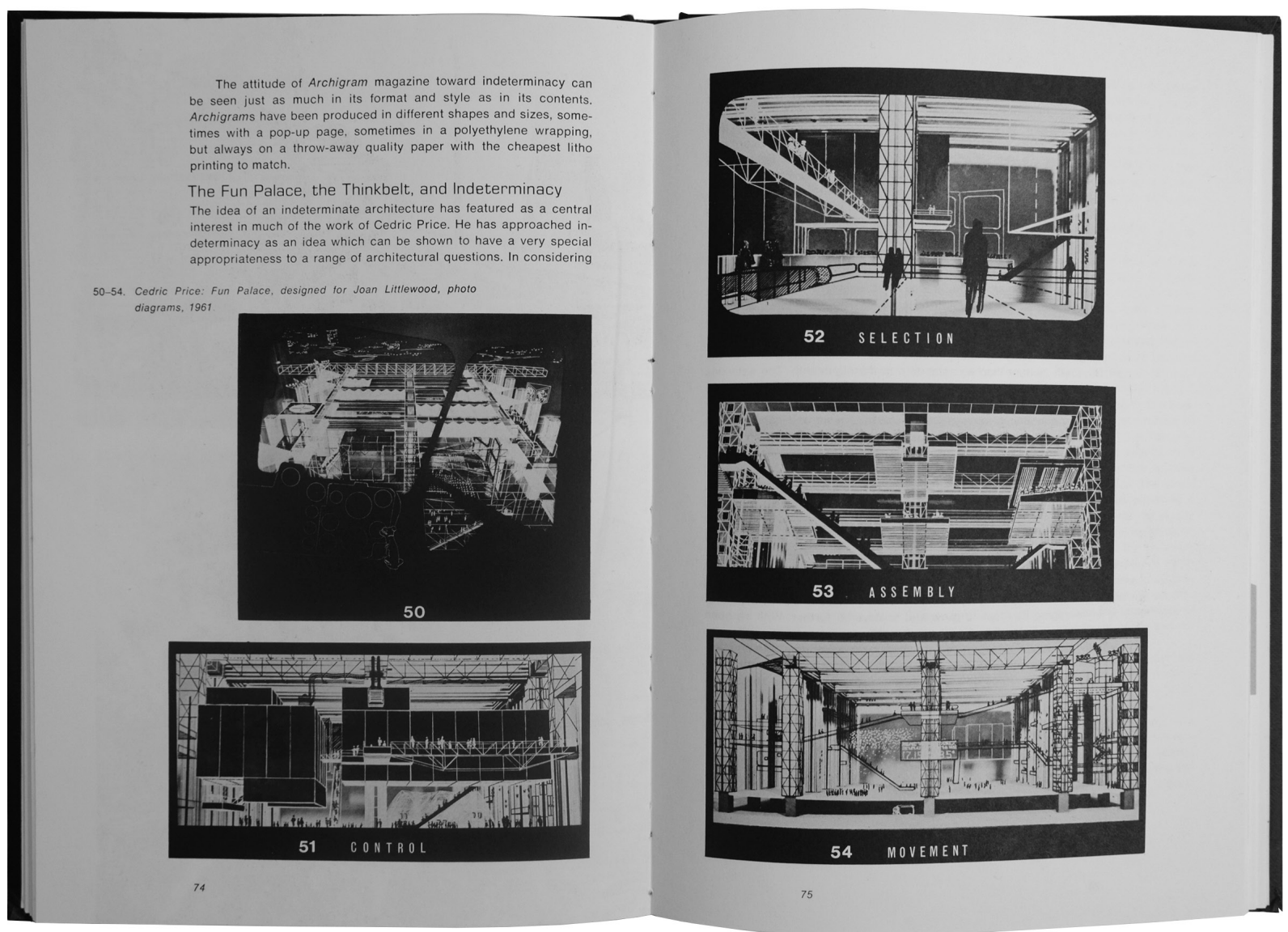


and Lionel March's "City Federation alternative building distributions plan," as well as with informational infrastructures for the range of databases implemented by the pioneering educational program in Britain at the time. Furthermore, Price's lexicon also leaks into Landau's closing remarks so as to underpin both the means and the ends of these non-architectures:

\footnotetext{
"The certainty which was a part of the classically discrete programme has moved towards a fluid but calculated uncertainty / So if architecture is becoming mathematical at one level and anti-building at another, perhaps it should be classified as not architecture ... but this would signify that it had taken a New Direction" (fig. 03). ${ }^{12}$
}

Landau pursued his investigation of non-architectures further in two editorial projects for Architectural Design in 1969 and 1972. Within the multidisciplinary forum defined for the first of these projects, Gordon Pask's “The Architectural Relevance of Cybernetics" designates the Fun Palace as a model for a cybernetic design paradigm, which conceives of architecture as an interactive and evolving system governed by the users' feedback, rather than as a building. Contributing to Landau's second editorial, Price's "Approaching an Architecture of Approximation" presented "Non-Plan," a joint research project conducted in cooperation with Reyner Banham, Peter Hall, and Paul Barker for New Society, which challenges the fragmentary approach to the planning of British "New Towns" with a program that integrates "doubt" and is open to reassessing the entire order of the priorities given. ${ }^{13}$

The uneasy association between the visionary and pragmatic responses to non-deterministic planning since Banham's article "Clip-on Architecture," namely, respectively those by Archigram and in Colin Buchanan's report Traffic in Towns (1963), would be subjected to intense interrogation at the turn of the decade. Megastructures had been critically appraised in Peter Hall's "Monumental Folly" for their flawed fiction, and for the clearance space that these oversized structures effected in the fabric of British towns when realized..$^{14}$ They were thus called into question by Alan Colquhoun in "Typology and Design Method." "15 The Canadian architect Melvin Charney explicitly referred to the Fun Palace when appraising the cultural role of megastructures. Beyond their ultimately obsolete technology, megastructures were analogues for novel modes of social organization that build probability into their performance. "They are exciting," claimed Charney in "Environmental Conjecture: In the Jungle of the Grand Prediction" -"because they oppose processes that inhibit the full articulation of technology."16 The expendable Fun Palace thus became, on the pages of Alvin Toffler's Future Shock, a powerful image of the distress and disorientation endured by the transient society of the 1960 s. ${ }^{17}$

The optimism emanating from the idea of self-organization in the 1960s turned by the end of the decade into a more critical appraisal of its subservience to profit and power. In the aftermath of May 1968, a different kind of architectural criticism emerged, which scrutinized these effects from theoretically informed positions -critical theory, semiotics, structuralism, and phenomenology, as Michael Hays has claimed.18 At the beginning of Hays' anthology, the Marxian critic Manfredo Tafuri argued against architecture's flawed ideological positions, and affirmed the impossibility of an emancipatory architecture in a situation in which capitalist articulation commands the formalization of the discipline. ${ }^{19}$ Meanwhile, 
claims of value-free, objective design were exposed by studies informed by semiotics, such as George Baird's '"La Dimension Amoureuse' in Architecture," who criticizes the elimination of meaning in the utilitarian rhetoric of Price's Potteries Thinkbelt. ${ }^{20}$

In this context, Peter Cook's shallow critique of various visionary projects of the 1960 s, including the Fun Palace, in his Experimental Architecture (1970) may feel outdated. ${ }^{21}$ For even Banham's wholehearted support for the discourse on megastructures of the 1960s would grind to a halt at the turn of the decade -and so, by 1972, we find him declaring that "the megastructure is dead and time has come to write its history."22 Banham's Megastructure: Urban Futures of the Recent Past (1976) presented an image of the Fun Palace as a buildable fact -supported by the selection of the Fun Palace model along with three photomontages of the project. Banham's belief in the technical competency of the Fun Palace, combined with the project's ability to retain its conceptual mobility, precluded the ideological critiques launched against Archigram's work, which Banham excuses as "British graphic opportunism," ${ }^{23}$ the surrender of the vague environs of Constant's New Babylon to consumerism, according to Situationist peers, ${ }^{24}$ as well as the stasis of the Centre Pompidou, which, by 1976 , had nearly been completed. ${ }^{25}$ Urged on perhaps by the ambivalence surrounding the architectures of indeterminacy at the turn of the 1970s, Price validated the Fun Palace's heuristic design methods when reviewing the early Fun Palace Chart "Comparative Theatre Seating Analysis. 51/30" in the "Cedric Price Supplement" to Architectural Design of 1971: "It is still a bloody good crib sheet although it has a disturbing similarity with those charts of how to lay out slaves on a ship's deck."26

Based on Banham's megastructure aesthetics and Landau's informational rhetoric, the architectural scholarship in the 1960s and early 1970s heralded the alterity with which the project's indeterminacy confronted the dominant canon of modern architecture. This image of non-architecture crystalized in the mesmerizing photomontages and other spatial visualizations of the project, at the expense of the gridded diagrams for the project, which made the claim of indeterminacy possible. Moreover, this technologically enthused scholarly tradition obscures one entire area of the project's cultural activity and neutralizes the critical role that Littlewood played in its development. Such selective gestures mirror the expectations of the discipline at the time. ${ }^{27}$

FUN PALACE AFTERLIVES SINCE 1999
The lively interest in the Fun Palace waned by the second half of the 1970s due to the limited opportunities for practice and the turn to theory in architectural discourse. Price was the only one of the Fun Palace collaborators who continued to show images of the major project and situate it within his later practice -thus it appeared-in his two solo exhibitions in London The Evolving Image (1975) ${ }^{28}$ and Cedric Price (1984), ${ }^{29}$ and lectures such as "Technology Is the Answer But What Was the Question?" $(1979)^{30}$ and "Autumn Always Gets Me Badly" (1989). ${ }^{31}$

It would not be until 1999 that a renewed interest in the revision of modernist principles during the postwar period reactivated Fun Palace scholarship in architectural discourse. ${ }^{32}$ The book $A n x-$ ious Modernisms: Postwar Architectural Culture, 1943-1968 (2000) 
explored the complex synergies across postwar architectural experimentation and the former modernist tradition so as to challenge the reception of the latter as an expired style. ${ }^{33}$ In the publication, the key paper by Mary Louise Lobsinger, "Cybernetic Theory and the Architecture of Performance: Cedric Price's Fun Palace," reassessed the project's mediation of technology. Lobsinger commented skeptically on the potential capitalist affiliations of the project's free-choice rhetoric and suggested that the deployment of the diagram as a method of visual analysis remained its most relevant contribution to architectural theory. Crucially, the paper enhances the visual commentary associated with the project's technical capacity by means of gridded figures such as the cybernetic script by Gordon Pask, "Organisational Plan as Programme." ${ }^{34}$ Simon Sadler and Jonathan Hughes's anthology Non-Plan: Essays on Freedom, Participation and Change in Modern Architecture and Urbanism (2000) explored the debates of the 1960s on democratizing decision-making processes, which undermined architectural determinacy, ${ }^{35}$ inviting Price, Paul Barker, the editor of New Society, and other protagonists of the period to reflect on their work. Price's "Non-Plan Diary" collates a Fun Palace montage in his synthetic image-plus-commentary cut-up genealogy. ${ }^{36}$ Following the bequest of the Howard Gilman Collection to the Museum of Modern Art in New York in 2000, the exhibition The Changing of the Avant-Garde at MoMA (2002) animated the ongoing celebration of postwar architecture. Two hundred and five drawings, including five of the Fun Palace, visually constructed the transition from megastructures to theory-informed postmodernism. ${ }^{37}$ Meanwhile, the curator Hans Ulrich Obrist's Cedric Price Drawings (2001) staged the Fun Palace's promotional broadsheet as the exhibition's foldable catalogue.$^{38}$ And in Obrist's editorial project $R e: C P$ (2003), a heterogeneous and rich catalogue of Price's annotated commentary, he celebrated the significant attention paid to the Fun Palace in Japan at the time with the translation of Arata Isozaki's article "Erasing Architecture into the System" of $1975 .{ }^{39}$ Joan Littlewood passed away on September 2002 and Cedric Price less than a year later, in August 2003. The Fun Palace subsequently reverberated throughout the obituary pages dedicated to both personalities. In the editorial "Cedric Price Disappears" (2004), the architecture patron and collector Niall Hobhouse discussed the alterity of Price's work as "the long-run Cedric Price Project" and situated the Fun Palace at its apex. ${ }^{40}$ Illustrated with some of the project's photomontages, Hobhouse aptly commented on how "the almost infinite broadening of the programme, and the relentless effacement of the designer that went along with it, led, both in a sort of formal reductio, and also in fact, to its not being built."41 In October 2003, the exhibition Out of the Box: Price Rossi Stirling + Matta-Clark opened at the Canadian Centre for Architecture to celebrate the recent constitution of these archives. The section on Price by the architectural theorist Mark Wigley, ungrounded over 200 Fun Palace records, most of them not yet catalogued at the time, so as to destabilize the architectural image of the project. ${ }^{42}$ From this vast periphery of the project's media emanated an image of the project as a complex research program, one that gave Price his "anti-architect" persona. Editing out architecture was an approach to challenging a discipline that Price perceived-claims Wigley- as loaded with stupidity. The exhibition and related article in Domus, "Cedric Price's Fun Palace: Anti-Buildings and 
Anti-Architects," disseminated the Fun Palace image of anti-building and situated its centrality in Price's lifelong project. Yet the complex topography of the Fun Palace's production -which not only avoided the worn-out montages, but also neglected to include a range of Fun Palace records that are archived outside of the institution's collection ${ }^{43}$ - was tightly tied to Price's "secret laboratory." ${ }^{4}$ As Wigley recalled during a later event at the CCA, the Fun Palace was "the laboratory within which Price invented himself as a kind of an anti-architect." ${ }^{\text {"45 }}$ For the architectural public, this sort of commentary deactivates the energy that Littlewood invested in the project and permeates the Cedric Price fonds.

Under the auspices of the CCA, the image of the Fun Palace as a research-guided anti-building would circulate intensively in architectural scholarship with a focus on Price's work. ${ }^{46}$ The riches of Price's archive nurtured a number of close scholarly studies on the Fun Palace. The first detailed historiography of the project, Stanley Mathews's From Agit-Prop to Free Space: The Architecture of Cedric Price (2007), situated Joan Littlewood's interests and concurrent professional work within the rise of the Fun Palace. ${ }^{47}$ Samantha Hardingham's Cedric Price Works 1952-2003: A Forward-Minded Retrospective (2016) systematically catalogued Price's prolific professional career and mediatized a substantial part of his archive. ${ }^{48}$ This important and encyclopedic collection surely invites further scholarship on Price. Complementary to Hardingham's book, Tanja Herdt's The City and Architecture of Change: The Work and Radical Visions of Cedric Price (2017) interwove the Fun Palace with Price's concurrent and subsequent projects so as to situate his approach to architecture as a social system with broader urban implications within British postwar culture. ${ }^{49}$

Alongside Price-centered scholarship and the way in which his legacy has permeated historiographies on postwar architectural experimentation since 1999, discussions of the project in architectural theory gave rise to various contemporary preoccupations of the discipline, such as those of authorship, flexibility, and indeterminacy. Tim Anstey's "Architecture and Rhetoric: Persuasion, Context, Action" (2007) thus assessed the ambivalent authorship of Price's practice as it is conveyed in the Fun Palace as one that is highly contingent with regard to the control exerted over architectural form, but dictatorial with regard to architectural representation. The project's diffuse and interdisciplinary production questioned the self-sufficient nature of architectural action that was constitutive of the modern tradition, as well as the hegemony of architectural drawing that went along with it. Anstey cleverly selected the chart "Camden Town Pilot: Network Analysis. 51/121" to argue how the Fun Palace diagrams revealed Price's tight command over the affects that these radical representations propagate in order to persuade their audiences, and situated this kind of authorship in the long tradition of the Albertian model of the architect, one whose authority governs rhetoric rather than the building site..$^{50}$ Adrian Forty's Words and Building: $A$ Vocabulary of Modern Architecture (2000) discussed the ambivalent contribution of the Fun Palace to the language of modern architectural criticism with respect to its technically driven flexibility and formlessness. For it is the Fun Palace's technical flexibility that tethers the project to the modernist functionalist canon, while its indeterminate form keeps it loose. ${ }^{51}$ For their part, historiographies of digital culture eagerly revisit the encounter of the Fun Palace with cybernetics. 
Yet, within the intense circulation of the project, some of its contemporary representations diverge noticeably from the activist agenda that the Fun Palace pursued in British institutionalized culture. The radical and mundane spontaneity envisaged by Littlewood and Price feels distant in the exhibition Lucius Burckhardt and Cedric Price-A stroll through a fun palace, curated by Obrist and Lorenza Baroncelli for the Venice Architecture Biennial in 2014. ${ }^{52}$ Strictly regulated and surveilled, the exhibition staged a simulated archive, with facsimiles of a quite broad selection of records from Price's archive, which were faithfully reproduced in size, color, and archival reference, alongside the original model of the Fun Palace (fig. 04). Some of these reproductions re-circulated years later in "A stroll through the fun palace," part of the two-week cultural program A Prelude to The Shed (2018), which promoted the cultural center The Shed, which was still under construction in the lucrative Hudson Yards real estate development in Manhattan.

Architectural scholarship has thoroughly examined the Fun Palace within the context of Cedric Price's body of work. With historical distance, it is now celebrating and critically reassessing the project's dynamism and openness as an architectural response to the anxieties of the British postwar period. Yet the cultural complexity of the project is only partially conveyed in this scholarly mode of reception. As was the case in the accounts of scholars of the late 1960s and early 1970s, Littlewood is presented as a rather neutral figure, and those practices
Fig. 04

Hans Ulrich Obrist and Lorenza Baroncelli, "Lucius Burckhardt and Cedric Price-A stroll through a fun palace," Swiss Pavilion, 14th Venice Architecture Biennial, 2014. Photograph by the author.

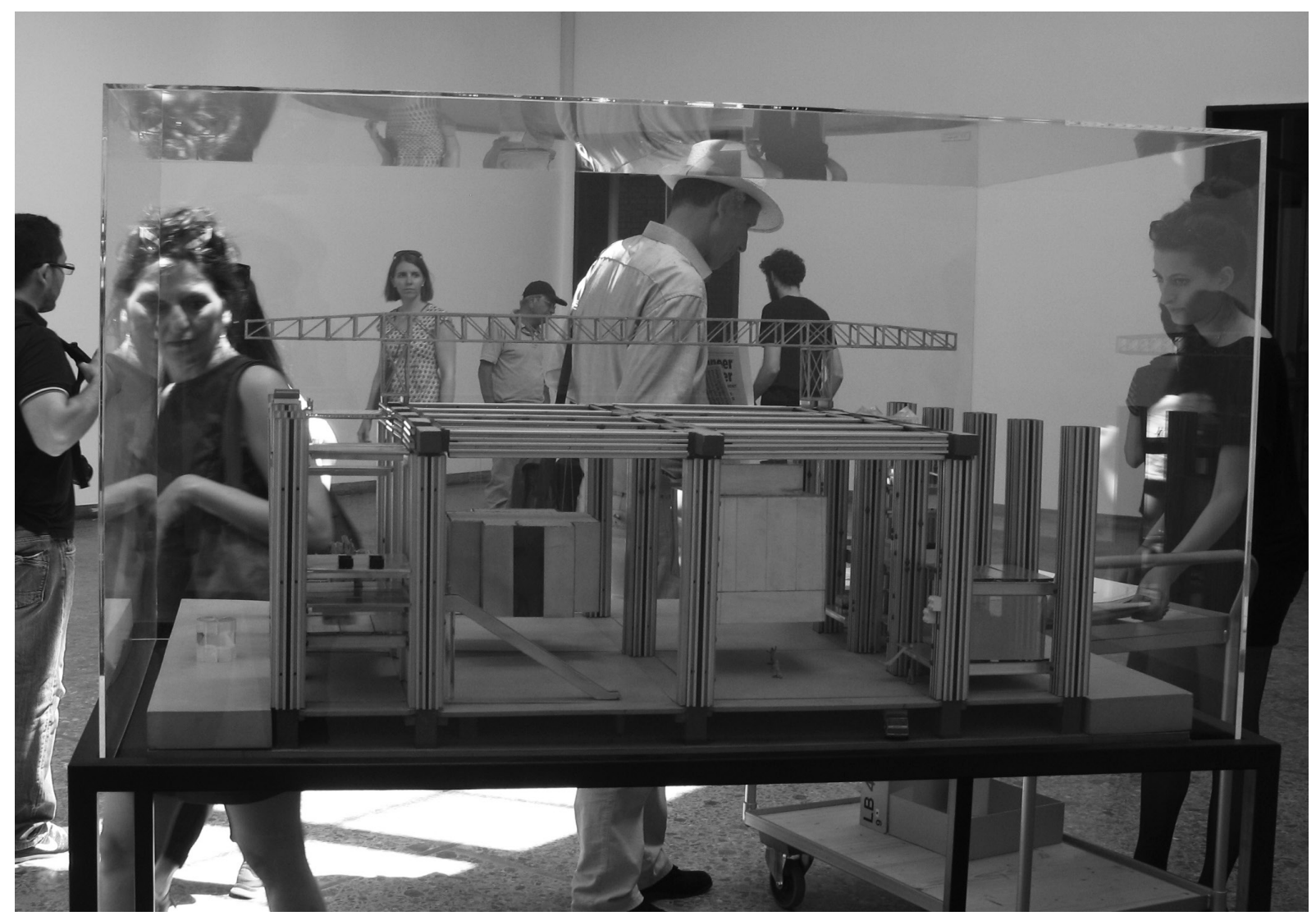




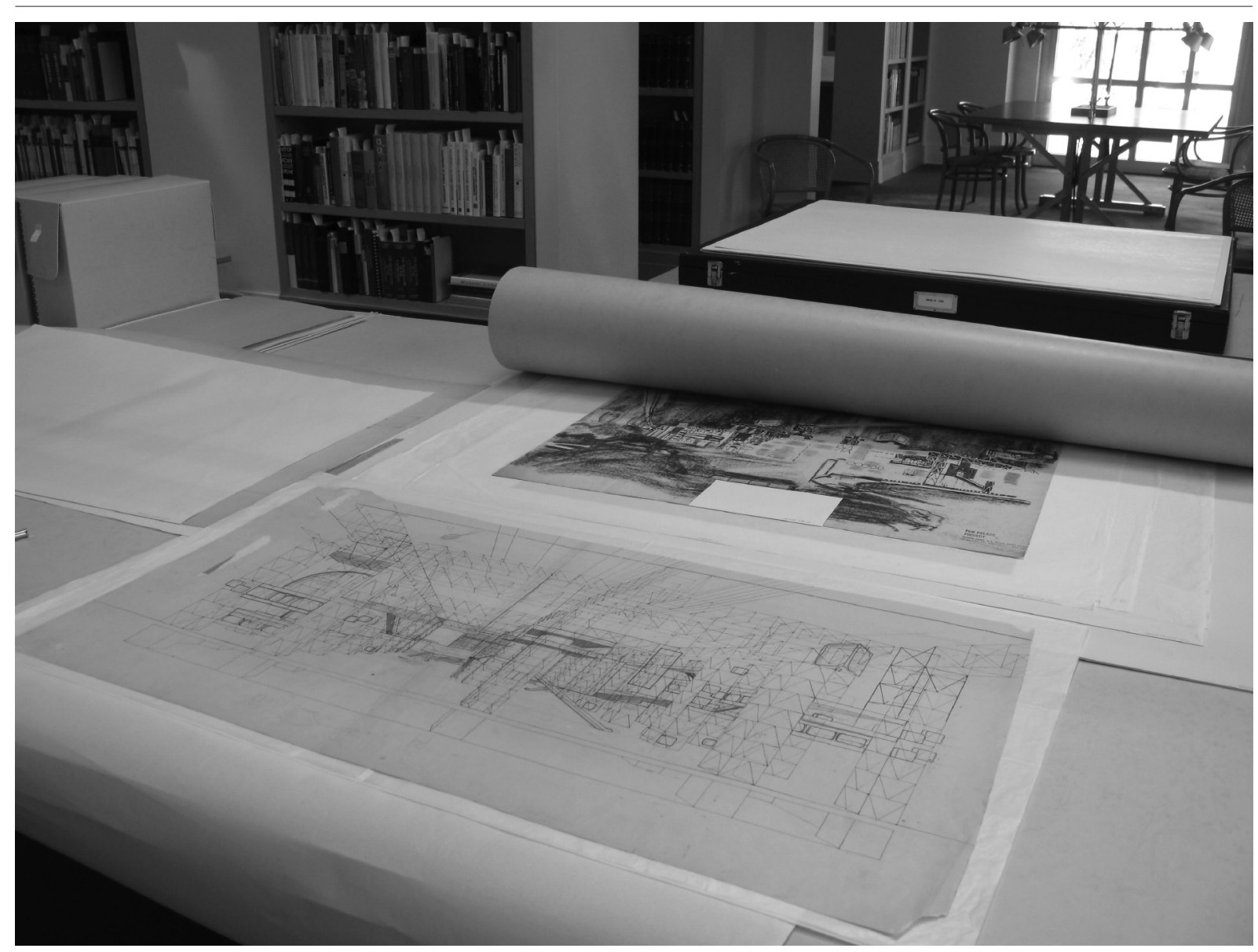

05

Fig. 05

Research at the Canadian Centre for Architecture, April 2015. Photograph by the author. that problematize the Fun Palace as an architectural endeavor, such as the range of publicity through which the project was constituted and transformed and the range of community activities associated with the Stratford Fair, continue to challenge scholarly architectural practice.

Meanwhile, it is through complementary studies on Littlewood on the one hand, and a range of alternative, non-scholarly initiatives inspired by Littlewood's legacy on the other that the distributed authorship of the project and its cultural agenda are being brought up to date for today. Theatre scholars such as Nadine Holdsworth and Robert Leach, and individuals working across disciplines such as Juliet Rufford, situate Littlewood's theatre practice, the Fun Palace, and her community work in Stratford as part of her struggles with the broad spectrum of British postwar institutions. ${ }^{53}$ In addition, a number of representations of the Fun Palace guided by artistic practice convey an alternative, activist mode of reception that challenges scholars' selective attention to the project. In the best spirit of the fair, the yearly, UK-based cultural campaign "Fun Palaces," organized by Stella Duffy and Sarah-Jane Rawlinson since 2014, ${ }^{54}$ Mel Brimfield and Gwyneth Herbert's hybrid performance "The Palace that Joan Built" (2014), ${ }^{55}$ Wendy Richardson's memory bank "In the Company of Joan" (2016), ${ }^{56}$ and Caroline Bird's poem-installation The Fun Palace at the Olympic site in East London $(2011)^{57}$ are manifestations 
that have actualized the cultural democracy that the project pursued. For the critic Chantal Mouffe, artistic activism is a mode of counter-cultural practice that actively engages with institutions in order to unsettle the consensus established by dominant formations in public discourses and spaces. Mouffe outlines an agonistic model for pluralist democracy that is grounded in dissent. Politics is precisely that mode of practice that delineates systemic limits and pluralizes hegemonies in manifold realizations. ${ }^{58}$ The critical role of artistic practice is then that of producing alternative images -as Mouffe claims- so as to "mak[e] visible what the dominant consensus tends to obscure and obliterate, [and] giv[el a voice to all those who are silenced within the framework of the existing hegemony."59 The complexity embodied in these scholarly and activist image-registers of the Fun Palace since 1999 invites an examination of the nature of the Fun Palace archive and its agency.

THE COMPLEX FUN PALACE ARCHIVE
The eruption of Price-centered scholarship after 1999 followed the constitution of major sections of the Fun Palace archive in key research institutions during the 1980 s and 1990 s. The custodian of the most extensive collection of Fun Palace materials, the Cedric Price fonds, has been part of the holdings of the 40,000-square-meter Canadian Centre for Architecture in Montreal since the fonds was constituted in 1995. Founded by the Canadian philanthropist and architect Phyllis Lambert in 1979 to actively explore, promote, and disseminate international scholarship on the history and theory of architecture and the built environment, the Canadian Centre for Architecture has exerted a remarkable impact on the scholarly reception of the Fun Palace. With a systematic catalogue accessible online, research on Price is further supported by the institution's active patronage.$^{60} \mathrm{~A}$ stable network of scholars, institutions, and discourses has been consolidated as a result. These yield key scholarship on the Fun Palace, yet one that calibrates the project's architectural valence (fig. 05). Complementing this major archive, MoMA's Gilman Collection (2002) holds five key drawings of the project; the St John's College Library, Cambridge, has held Price's notebooks and other personal records since 2012; some of Price's articles form the holdings of the Cedric Price Papers at RIBA, London (2003); Price's robot collection is part of the private institution Drawing Matter; and recordings of his lectures are becoming progressively available via the YouTube channel of the AA School of Architecture.

In contrast to the institutional stability of Price's archive, Littlewood's archive is fragmented. A range of unsigned and uncatalogued carnivalesque memos that are distinctively Littlewood's spring from unexpected locations in the Cedric Price fonds and punctuate the confidence of his archive with her timely critique. For instance, in the humorous, handwritten memo "OL.CON.COME.HERE" -a play on words on the acronym for the Oxford Corner House project- on a sheet of Price's typical, preformatted letterhead and addressed to "Le Grand Anti-Arc," Littlewood warns of the parasitic "con" that is built into the brief for the project "All Can Come Here," commissioned by the "Oh the lovely capitalists." In this "communications report," Littlewood appears to foresee traces of obsolete thinking in the misrepresentation of universally accessible pleasures within the framework of the 


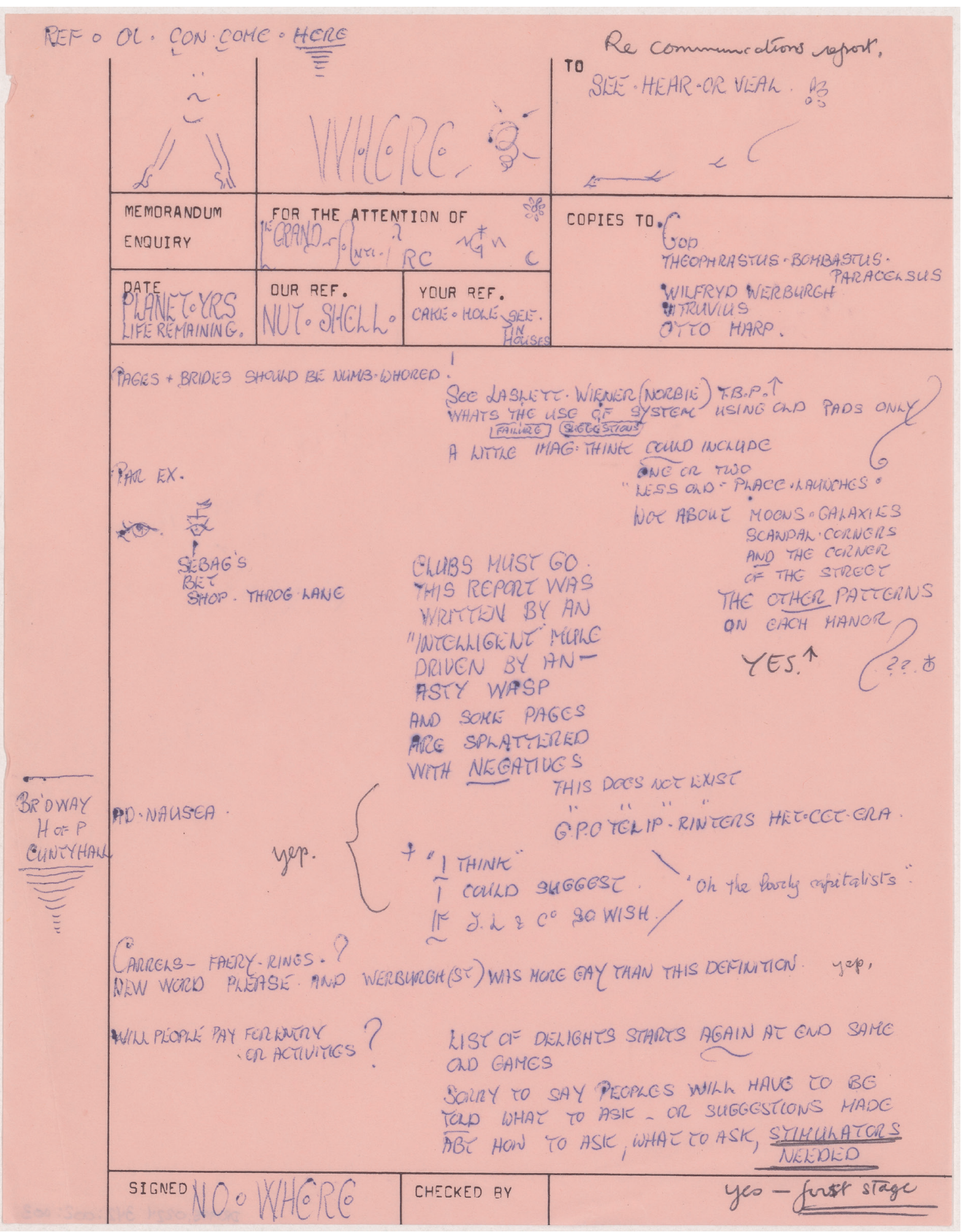


profit-driven British tea company Lyons \& Co -"cake hole"- with which Price cannot but concur with humble annotations - "yep" or "yes- first stage" (fig. 06). ${ }^{61}$ Remnants of what might possibly be a collection of Littlewood's notebooks and few Stratford Fair records have been part of the Michael Barker Collection of Joan Littlewood and the Theatre Workshop at the Harry Ransom Center, University of Texas, Austin, since 1980. The obscure provenance of this collection seems to be associated with a theft under the conditions of financial instability that surrounded Littlewood's career. ${ }^{62}$ The London County Council Collection at the London Metropolitan Archives (1953) and the Arts Council of Great Britain Archive at the Victoria \& Albert Museum Collection (1996) offer access to a number of planning and grant applications for the project. Footage from the Fun Palace film is split between the Cedric Price fonds and the British Film Institute National Archive, part of the latter of which has been partially available online since 2014 . The British Library recently received the Theatre Royal Stratford East Archive Collection (2020), with its thin Fun Palace folders, as part of the Theatre Workshop Collection. ${ }^{63} \mathrm{~A}$ portion of Littlewood's library was still at Theatre Royal when I visited it in 2015. Other sparse records are held by smaller private collections, such as the Peter Rankin Estate and the Clive Barker Personal Archive. The suite of anecdotes curated by Littlewood in her fictional autobiography, Joan's Book (1994) barely fills the gaps. ${ }^{64}$ Neither do the living memories found in conversations with her close collaborators, some of them sedimented in the few scholarly studies on Littlewood that exist today. ${ }^{65}$

The Fun Palace archive is uneven territory: as a constellation of public and private institutions that work independently, their differential agency is driven by the nature and accessibility of each respective collection, as well as by the sort of patronage endowed by each host in connection with the dissemination of the project. The section on Price is systematic and affirmative, while the section on Littlewood, fragmented and fugitive, is decanted as "other" in the asymmetrical Fun Palace archive. As a shadow casted upon the reception of the Fun Palace, whose afterlife spans almost sixty years, the complex form of the Fun Palace archive inevitably marks the horizon of possibilities to make systematic statements about the project. While architectural scholarship tirelessly explores the riches of Price's archive and Littlewood's scholars navigate her sparse papers held across the globe for their respective academic audiences, Littlewood's memory-in-exile holds open the regenerative potential of the Fun Palace as a cultural project. Activist practices reveal "other" images of the project so as to suture the gaps in her non-archive. Their discourse is mimetic, their public universal. Their cultural role is that of actualizing the public agenda of the Fun Palace within the discursive field of the reception of the Fun Palace. For they give voice to those silenced in active readings of the archive. This complex topology of the archive, which is constitutive of the project's distinctive modes of reception and their tempo, nurtures those affects, whether historical, theoretical, or activist, that situate each image, and each absence, in the contingencies of its own time. RA
Fig. 06

Cedric Price. Notes for Oxford Corner House Feasibility Study. 19651966. Ink on paper. $25.5 \times 20.5 \mathrm{~cm}$. DR1995:0224:342:002:003, Cedric Price fonds. Canadian Centre for Architecture. 


\section{Acknowledgments}

I am grateful to Prof. Mark Dorrian and Dr. Ella Chmielewska for important comments and suggestions made during the development of this article.

01. The exhibition traveled to the Museum of Modern Art, Saitama, the Niigata City Art Museum, the Hiroshima City Museum of Contemporary Art, and the National Museum of Art in Osaka between February 2019 and February 2020. IGARASHI, Taro (ed.), Impossible Architecture, trans. Pamela Miki Associates and Christopher Stephens, exh. cat. Museum of Modern Art Saitama; Niigata City Art Museum; Hiroshima City Museum of Contemporary Art; The National Museum of Art, Osaka, Heibonsha Limited Publishers, Tokyo, 2019; https://stichtingconstant.nl/ bibliography/impossible-architecture (all URLs here accessed in July 2021)

02. DE LA O CABRERA, Rodrigo (curator), An Atlas of Architectural Theory, Círculo de Bellas Artes, Madrid, February 14-May 26, 2019. Samantha Hardingham, Scrap Marshall, Jan Nauta (curators), Cedric Price: Room for Learning, Woodbury University Hollywood, Los Angeles, October 19-November 23, 2019.

\section{3. https://theshed.org/about/building}

04. mOOO Architecture Design Competitions, "Macau [ Morphosis ] WATERFRONT FUN PALACE," in ArchDaily, August 5, 2019, https://www. archdaily.com/922350/open-call-macaumorphosis-waterfront-fun-palace

05. For instance, the curator Mimi Zeiger reflects on contemporary representations of visionary architectures of the 1960s, such as The Shed, as abstractions that limit the current capacity for architectural speculation. ZEIGER, Mimi, "Feedback Loops: Or, Past Futures Haunt Architecture's Present," in Architectural Design, 2019, 89, 4, pp. 46-53. Yaneva Albana discusses the impact of archival conservation practice on the ephemeral materiality of the Fun Palace model. ALBANA, Yaneva, "Giants in the lab: Model conservation and the anaphoric progression of design," in Journal of Material Culture, January 26, 2021, pp. 85-105. Chase Galis reflects on the construction of light by means of rendering techniques in the Fun Palace drawings in "The Fun Palace: Light Adaptation," January 8, 2021, www.drawingmatter. org. My own text "Cedric Price: Urban Spaceman," March 22, 2021, www. drawingmatter.org, supplements these reflections.

06. WILLIAMS, Raymond, The Long Revolution, Pelican Books, Harmondsworth, 1965, pp. 66-68.

07. BANHAM, Reyner and the Walker Art Center, A Clip-on Architecture, Walker Art Center, Minneapolis, 1965, p. 3. Before this, Banham briefly published his support for the project in the article "People's Palaces" for the newspaper New Statesman, August 7,1964 , a year when the project was disseminated intensely in the British press.

08. PRICE, Cedric, "Fun Palace Project," in The Architectural Review, January 1965, 137, 815, pp. 74-76.

09. BANHAM, Reyner, "A Clip-On Architecture," in Design Quarterly, 1965, 63, pp. 14-15; https://doi.org/10.2307/4047309

10. The Fun Palace, Price's Potteries Thinkbelt, and Archigram's expendable experiments dovetail with the speculative work of Paolo Soleri, Yona Friedman, the Japanese Metabolists, Hans Hollein, Paul Virilio, and Claude Parent, Buckminster Fuller, and Frei Otto, among others. ARCHIGRAM, "International Dialogue of Experimental Architecture" (IDEA), Folkestone, June 1966; http://archigram. westminster.ac.uk/project.php?id=83

\section{ANDERSON, Stanford (ed.), Planning} for Diversity and Choice: Possible Futures and Their Relations to the Man-Controlled Environment, The MIT Press, Cambridge, MA, 1968, p. 286.

12. LANDAU, Royston, New Directions in British Architecture, G. Braziller, New York, 1968, p. 115.

13. PRICE, Cedric, "Approaching Architecture of Approximation," in LANDAU, Royston(ed.), "Complexity and Complexing," Architectural Design, October 1972, pp. 645-46.

14. Despite Hall's interest in exploring modes for loosening planning legislation in Britain, which he pursued through the speculative proposal jointly conceived with Price, Banham, and Paul Barker, the editor of New Society, "Non-Plan: An Experiment in Freedom," 1969, he was disenchanted by the limited freedom afforded by rhetoric on megastructures. HALL, Peter, "Monumental Folly," in New Society, October 24, 1968, 12 , 317, pp. 602-03.

15. COLQUHOUN, Alan, "Typology \& Design Method," in Charles Jencks and George Baird (eds.), Meaning in Architecture, Barrie \& Rockliff, The Cresset Press, London, 1969, p. 268.

16. One of the Fun Palace photomontages illustrates the argument. CHARNEY, Melvin, "Environmental Conjecture in the Jungle of the grand Prediction," in ANDERSON, Stanford (ed.), Planning for Diversity and Choice: Possible Futures and Their Relations to the Man-Controlled Environment, The MIT Press, Cambridge, MA, 1968, p. 326.

17. TOFFLER, Alvin, Future Shock, Random House, New York, 1970, p. 59.

18. HAYS, K. Michael, Architecture Theory Since 1968, The MIT Press, Cambridge, MA, and London, 1998, pp. xvi-xviii.

19. TAFURI, Manfredo, "Toward a Critique of Architectural Ideology," in Contropiano, 1969,1 , an argument that is expanded on in "Architecture and Utopia," 1976, in Hays, Architecture Theory Since 1968, pp. 2-36.

20. BAIRD, George, "'La Dimension Amoureuse' in Architecture," 1969, in Hays, Architecture Theory Since 1968, pp. 36-55.

21. COOK, Peter, Experimental Architecture, Studio Vista, London, 1970, pp. 141-42.

22. DEYONG, Sarah, "Memories of the Urban Future: The Rise and Fall of the Megastructure," in Terence Riley (ed.), The Changing of the Avant-Garde: Visionary Architectural Drawings from the Howard Gilman Collection, exh. cat. The Museum of Modern Art, D.A.P./Distributed Art Publishers, New York, 2002, p. 30.

23. BANHAM, Reyner, Megastructure: Urban Futures of the Recent Past, Harper and Row, New York, 1976, p. 83.

24. Ibid., p. 101.

25. Ibid., p. 211. 
26. PRICE, Cedric, "The Second Instalment in the Cedric Price Supplement Series," in Architectural Design, January 1971, 41, p. 25.

27. The promotional film, the marginalia, and the press articles produced were part of an ambitious publicity agenda designed by Littlewood, Price, and the journalist Tom Driberg to actively contest the impact of corporate mass communications in Britain at the time. Similarly, the range of community playgrounds and fair events in Stratford that Littlewood initiated between 1967 and 1975 and that organized local youth politically amidst the violent urban redevelopment in the area. All of them conveyed the project's cultural agenda, but did not elicit architectural interest at the time. See BONET MIRÓ, Ana, "From Filmed Pleasure to Fun Palace," in Arq (London, England), 2018, 22, 3, pp. 215-24; and "On Playgrounds and the Archive: Joan Littlewood's Stratford Fair, 1967-1975," in Architecture and Culture, April 12, 2019, 6, 3, pp. 387-98.

28. PRICE, Cedric, The Evolving Image, Heinz Gallery, Royal Institute of British Architects, London, 1975.

29. PRICE, Cedric, Cedric Price: The Square Book, Wiley Academy, Chichester, 1984.

30. PRICE, Cedric, Technology Is the Answer, But What Was the Question?, Pidgeon Audio Visual, London, 1979.

31. PRICE, Cedric, Autumn Always Gets Me Badly, Architectural Association, London, 1989, AA Photo Library.

32. The postwar critiques of modernism were the subject of the two-part conference "Reconceptualizing the Modern: Architectural Culture, 1943-1968" at the Graduate School of Design at Harvard in 1998, and "Anxious Modernisms: Postwar Architectural Culture, 1943-1968" at the Canadian Centre for Architecture in 1999. The argument of postwar indeterminacy was also discussed at the conference "Structures and Practices" in,1997, which was organized by the Association of Art Historians in the United Kingdom.

33. This is the outcome of the two conferences organized at the Graduate School of Design, Harvard, in 1998, and at the Canadian Centre for Architecture, Montreal, in 1999.
34. LOBSINGER, Mary Louise, "Cybernetic Theory and the Architecture of Performance: Cedric Price's Fun Palace," in Sarah Williams Goldhagen and Réjean Legault (eds.), Anxious Modernisms: Experimentation in Postwar Architectural Culture, The MIT Press, Cambridge, MA, 2002, p. 131.

35. HUGHES, Jonathan, and SADLER, Simon, Non-Plan: Essays on Freedom, Participation and Change in Modern Architecture and Urbanism, Architectural Press, Oxford, 2000.

36. PRICE, Cedric, "Cedric Price's NonPlan Diary," in Jonathan Hughes and Simon Sadler (eds.), Non-Plan: Essays on Freedom, Participation and Change in Modern Architecture and Urbanism, Architectural Press, Oxford, 2000, p. 23.

37. RILEY, T., The Changing of the AvantGarde: Visionary Architectural Drawings from the Howard Gilman Collection, The Museum of Modern Art, D.A.P./ Distributed Art Publishers, New York, 2002.

\section{Cedric Price Papers, RIBA, London.}

39. ISOZAKI, Arata, "Erasing Architecture into the System," in Cedric Price and Hans Ulrich Obrist (eds.), Re $C P$, Birkhauser, Basel and Boston, 2003, pp. 25-45.

40. HOBHOUSE, Niall, et al., "Cedric Price Disappears," in AA Files, 2004, 50, p. 73.

\section{Ibid., p. 71.}

42. "In addition to any architect's usual accumulations of sketches, plans, working drawings, renderings, and models, there is a vast array of charts, reports, questionnaires, comparative lists, theoretical statements, film-scripts, minutes of scientific committees, punch cards, legal documents, fundraising brochures, statistics, diagrams of cybernetic circuits, newspaper clippings, electrical devices for generating random decisions, and so on." See WIGLEY, Mark, and SHUBERT, Howard, "II Fun Palace Di Cedric Price $=$ Cedric Price's Fun Palace," in Domus, January 2004, 866, p. 22.

43. For instance, Littlewood's collection of "Fun Palace outtakes" associated with the promotional film for the project, which is in the holdings of the British Film Institute National Archive, and Cedric Price's robot collection at Drawing Matter. The expanded geography of the Fun Palace archive today thus suggests a selective constitution of the Cedric Price fonds.

44. "The atmosphere of Cedric Price's studio was that of a secret laboratory -endlessly testing different possibilities in excruciating detail. Design was treated as a form of research... His way of destabilizing architecture was just to go deeper and deeper into each of its most basic operations. Research became a weapon... Instead of designing a building, he redesigned the figure of the architect," in Wigley and Shubert, "Il Fun Palace Di Cedric Price," p. 22.

45. WIGLEY, M., homage symposium "An Afternoon with Cedric Price \#2: Mark Wigley," CCA, Montreal, February 2017, min. 27:56; https://www.cca.qc.ca/en/events/41605/anafternoon-with-cedric-price-no-2

46. For instance, the four-month program "Fun Palace Berlin 200X: Cultural Centres for the 21st Century," Berlin, 2004, Juan Herreros's studio syllabus, "Palacios de la Diversion. Isla de San Miguel, Azores," School of Architecture in Madrid, 2004, and Barnabas Calder's exhibition Cedric Price: Thinking the Unthinkable, Glasgow, 2011.

47. MATHEWS, Stanley, From Agit-Prop to Free Space: The Architecture of Cedric Price, Black Dog Publ. Ltd., London, 2007.

48. It draws on the Cedric Price fonds at the CCA and Price's notebooks in the Cedric Price Collection at St John's College, Cambridge; see HARDINGHAM, Samantha, and PRICE, Cedric, Cedric Price Works 1952-2003: A Forward-Minded Retrospective, Architectural Association, London and Montreal, and the Canadian Centre for Architecture, 2016.

49. Alongside the Fun Palace, Herdt also discusses Price's Potteries Thinkbelt, the London Aviary Zoo, and the McAppy project, an investigation on building site safety; see HERDT, Tanja, The City and the Architecture of Change: The Work and Radical Visions of Cedric Price, Park Books, Zurich, 2017.

50. ANSTEY, Tim, "Architecture and Rhetoric: Persuasion, Context, Action', in Tim Anstey, Katja Grillner, and Rolf Hughes (eds.), Architecture and Authorship, Black Dog Publishing, London, 2007, p. 25. 


\section{Notes}

51. FORTY, Adrian, Words and Buildings: A Vocabulary of Modern Architecture, Thames \& Hudson, London, 2000, p. 171.

52. The curatorial team also included the scientific director of the pavilion, Lorenza Baroncelli, and the architects Herzog \& de Meuron. The exhibition was presented in the Swiss Pavilion at the Venice Architecture Biennial of 2014, and was sponsored by the Swiss Arts Council Pro Helvetia.

53. HOLDSWORTH, Nadine, "Spaces to Play/Playing with Spaces: Young People, Citizenship and Joan Littlewood," in Research in Drama Education: The Journal of Applied Theatre and Performance, 2007, 12, 3, pp. 293-304; idem, Joan Littlewood, Routledge Performance Practitioners, Routledge, London, 2006; idem, Joan Littlewood's Theatre Cambridge University Press, Cambridge, UK, and New York, 2011. LEACH, Robert, Theatre Workshop: Joan Littlewood and the Making of Modern British Theatre, Exeter Performance Studies, University of Exeter Press, Exeter, 2006.

54. DUFFY, Stella, and RAWLINSON, Sarah-Jane, "Fun Palaces," 2014-ongoing; https://funpalaces.co.uk/

55. BRIMFIELD, Mel, and HERBERT, Gwyneth, "The Palace That Joan Built," in Art on the Underground (blog), undated.

56. RICHARDSON, Wendy, In the Company of Joan, 2016; http://www.imdb.com/title/ tt7573474/plotsummary

57. "London 2012: Poetry in the Olympic Park -in Pictures," The Guardian, July 27, 2012, sec. Books; https://www.theguardian. com/books/gallery/2012/jul/27/poetryolympic-park-london-2012

58. MOUFFE, Chantal, Agonistics: Thinking the World Politically, Verso, London, 2013, p. xiii.

59. Ibid., p. 93.

60. The CCA grants access and reproduction of its records, and directly sponsors research programs related to Cedric Price such as the "British Architecture for Society," at https://www. cca.qc.ca/en/56738/multidisciplinaryresearch-program
61. Folder DR1995:0224:342:002, The

Cedric Price fonds, CCA.

62. HOLDSWORTH, Nadine, authorized interview with the author, January 19, 2016.

63. Records mainly related to the later Fun Palace episode, Stratford Fair, and various brochures concerning its reinterpretation today, Theatre Royal Stratford East Archives Collection.

64. LITTLEWOOD, Joan, Joan's Book: Joan Littlewood's Peculiar History as She Tells It, Methuen, London, 1994.

65. GOORNEY, Howard, The Theatre Workshop Story, Eyre Methuen, London, 1981); RANKIN, Peter, Dreams and Realities: The Official Biography, Oberon, London, 2014. RICHARDSON, In the Company of Joan.

\section{Abbreviations}

- AA

Architectural Association

- CCA

Canadian Centre for Architecture

- RIBA

Royal Institute of British Architects

- MoMA

Museum of Modern Art 


\section{Bibliography}

\begin{abstract}
- ANDERSON, Stanford, (ed.), Planning for Diversity and Choice: Possible Futures and Their Relations to the Man-Controlled Environment, The MIT Press, Cambridge, MA, 1968
\end{abstract}

- ANSTEY, Tim, "Architecture and Rhetoric: Persuasion, Context, Action," in Architecture and Authorship, Black Dog Publishing, London, 2007, pp. 18-29.

- BANHAM, Reyner, "A Clip-On Architecture," in Design Quarterly, 1965, 63, pp. 2-30. https://doi.org/10.2307/4047309. - Megastructure: Urban Futures of the Recent Past, Harper and Row, New York, 1976.

- BONET MIRÓ, Ana, "From Filmed Pleasure to Fun Palace," in ARQ: Architecture Research Quarterly, 2018, 22, 3, pp. 215-24. - "On Playgrounds and the Archive: Joan Littlewood's Stratford Fair, 1967-1975," in Architecture and Culture, April 12, 2019, 6, 3, pp. 387-98.

-BRIMFIELD, Mel, and HERBERT, Gwyneth, "The Palace That Joan Built," in Art on the Underground (blog), undated.

- COOK, Peter, Experimental Architecture, Studio Vista, London, 1970.

- FORTY, Adrian, Words and Buildings: A Vocabulary of Modern Architecture, Thames \& Hudson, London, 2000.

- GOORNEY, Howard, The Theatre Workshop Story, Eyre Methuen, London, 1981.

-HALL, Peter, "Monumental Folly," in New Society, October 24, 1968, 12, 317, pp. 602-03.

- HARDINGHAM, Samantha, and PRICE, Cedric, Cedric Price Works 1952-2003: A Forward-Minded Retrospective, Architectural Association, London, and Canadian Centre for Architecture, Montreal, 2016.

- HAYS, K. Michael, Architecture Theory since 1968, MIT Press, Cambridge, MA, and London, 1998.

- HERDT, Tanja, The City and the Architecture of Change: The Work and Radical Visions of Cedric Price, Park Books, Zurich, 2017.

- HOBHOUSE, Niall, ALSOP, Will, KOOLHAAS, Rem, and MCALPINE, Alistair, "Cedric Price Disappears," in AA Files, 2004, 50, pp. $70-79$.
-HOLDSWORTH, Nadine, Joan Littlewood's Theatre, Cambridge University Press, Cambridge and New York, 2011. - Joan Littlewood, Routledge Performance Practitioners, Routledge, London, 2006. - "Spaces to Play/Playing with Spaces: Young People, Citizenship and Joan Littlewood," in Research in Drama Education: The Journal of Applied Theatre and Performance, 2007, 12, 3, pp. 293-304.

- HUGHES, Jonathan, and SADLER, Simon, Non-Plan: Essays on Freedom, Participation and Change in Modern Architecture and Urbanism, Architectural Press, Oxford, 2000.

- IGARASHI, Taro, Impossible Architecture, edited by the Museum of Modern Art Saitama, trans. Pamela Miki Associates and Christopher Stephens; the Niigata City Art Museum; the Hiroshima City Museum of Contemporary Art; the National Museum of Art, Osaka, Heibonsha Limited Publishers, Tokyo, 2019; https://stichtingconstant.nl/ bibliography/impossible-architecture

- JENCKS, Charles, and BAIRD, George, Meaning in Architecture, Barrie \& Rockliff, the Cresset Press, London, 1969.

- LANDAU, Royston, New Directions in British Architecture, G. Braziller, New York, 1968.

- LEACH, Robert, Theatre Workshop: Joan Littlewood and the Making of Modern British Theatre, Exeter Performance Studies, University of Exeter Press, Exeter, 2006.

- LITTLEWOOD, Joan, Joan's Book: Joan Littlewood's Peculiar History as She Tells It, Methuen, London, 1994.

- LOBSINGER, Mary Louise, "Cybernetic Theory and the Architecture of Performance: Cedric Price's Fun Palace," in Sarah Williams Goldhagen and Réjean Legault (eds.), Anxious Modernisms, Canadian Centre for Architecture, Montréal, 2000, pp. 119-39.

- MATHEWS, Stanley, From Agit-Prop to Free Space: The Architecture of Cedric Price, Black Dog Publ. Ltd., London, 2007.

- mOOO Architecture Design Competitions, "Macau [ Morphosis ] WATERFRONT FUN PALACE," in ArchDaily, August 5, 2019; https://www.archdaily.com/922350/ open-call-macau-morphosis-waterfront-fun-palace
- MOUFFE, Chantal, Agonistics: Thinking the World Politically, Verso, London, 2013.

- OBRIST, Hans Ulrich (ed.), "Lucius Burckhardt and Cedric Price -A stroll through a fun palace, Swiss Pavilion, Venice Architecture Biennial, 2014, Swiss Arts Council Pro Helvetia, 2014.

- PRICE, Cedric, Autumn Always Gets Me Badly, Architectural Association, London, 1989, AA Photo Library.

- Cedric Price: The Square Book, Wiley Academy, Chichester, 1984.

- "Fun Palace Project," in The Architectural Review, January 1965, 137, 815, pp. 74-76. - The Evolving Image, Heinz Gallery, Royal Institute of British Architects, London, 1975. - "The Second Instalment in the Cedric Price Supplement Series," in Architectural Design, January 1971, 41, p. 25.

- PRICE, Cedric, and OBRIST, Hans Ulrich, Re CP, Birkhauser, Basel and Boston, 2003.

- PRICE, Cedric and Pidgeon Audio Visual, Technology Is the Answer, but What Was the Question?, Pidgeon Audio Visual, London, 1979.

- RANKIN, Peter, Dreams and Realities: The Official Biography, Oberon, London, 2014.

- RICHARDSON, Wendy, In the Company of Joan, 2016; http://www.imdb.com/title/ tt7573474/plotsummary

- RILEY, Terence, The Changing of the Avant-Garde: Visionary Architectural Drawings from the Howard Gilman Collection, The Museum of Modern Art, D.A.P./ Distributed Art Publishers, New York, 2002

- TOFFLER, Alvin, Future Shock, Random House, New York, 1970.

-WIGLEY, Mark, and SHUBERT, Howard, "I Fun Palace Di Cedric Price $=$ Cedric Price's Fun Palace," in Domus, January 2004, 866 , pp. 14-[23].

- WILLIAMS, Raymond, The Long RevoIution, Pelican Books, Penguin, Harmondsworth, 1965.
RA. Revista de Arquitectura Núm. 23 - 2021

P. $32-49$ 